\title{
Working
}

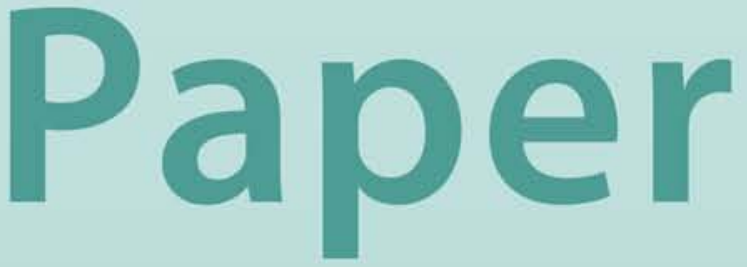




\title{
Spending Seigniorage: Do Central Banks Have a Governance Problem?
}

\author{
Alain Ize
}




\title{
IMF Working Paper
}

Monetary and Financial Systems Department

\section{Spending Seigniorage: Do Central Banks Have a Governance Problem?}

\author{
Prepared by Alain Ize ${ }^{1}$
}

March 2006

\begin{abstract}
This Working Paper should not be reported as representing the views of the IMF. The views expressed in this Working Paper are those of the author(s) and do not necessarily represent those of the IMF or IMF policy. Working Papers describe research in progress by the author(s) and are published to elicit comments and to further debate.

This paper reviews how central banks allocate seigniorage, based on systematic crosscountry comparisons of their financial accounts. Central banks are classified as weak or strong, depending upon their structural profitability. Weak central banks typically (although not exclusively) operate in smaller and less wealthy countries, lack independence from their governments, and are burdened by compulsory transfers and low capital. Their operating expenditures, nonperforming assets, international reserve carrying costs, and international reserve accumulation needs are high. Governance appears to be a potential concern in many central banks, both weak and strong, with operating expenditures often adjusting upward for high profitability and capital accumulation adjusting downward for low profitability. The main policy implications are briefly reviewed.
\end{abstract}

JEL Classification Numbers: E58, G21, H11

Keywords: seigniorage, governance, central banking

Author(s) E-Mail Address: aize@imf.org

\footnotetext{
${ }^{1}$ I am deeply indebted to Nada Oulidi for her patience and skills in carefully analyzing a very disparate information set of central bank financial statements, assembling it into a homogeneous data base, and conducting all the statistical analysis needed for this paper. Comments from participants in the MFD seminar are also gratefully acknowledged.
} 
I. Introduction

II. A Cross-Sectional Look at Central Bank Accounts ......................................................... $\underline{6}$

The data base .................................................................................... $\underline{6}$

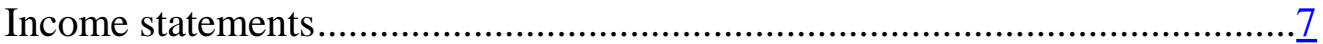

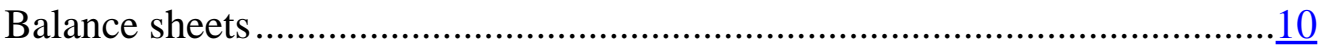

Bivariate statistical analysis ............................................................

III. Sources and Uses of Seigniorage ...................................................................... 14

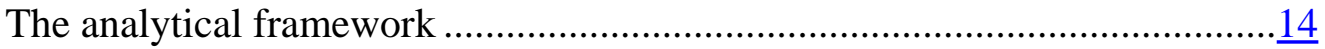

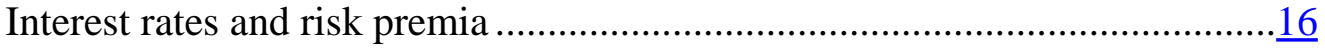

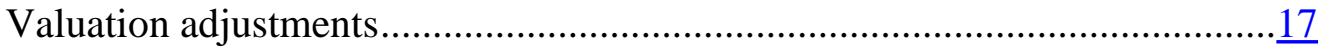

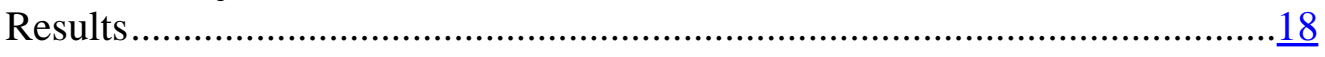

IV. What Determines Central Banks’ Operating Expenditures? ..........................................21

Are central bank expenditures demand or supply driven?...........................21

Are countries getting their money's worth in central banking services?..........24

V. Conclusions.

Appendixes

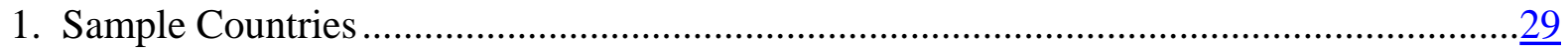

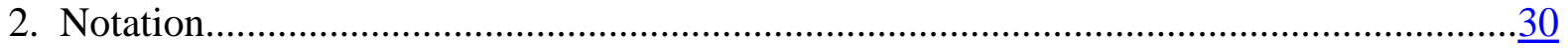

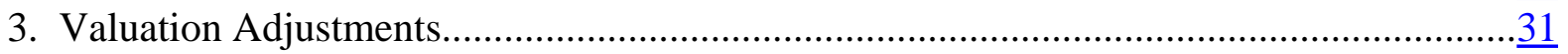

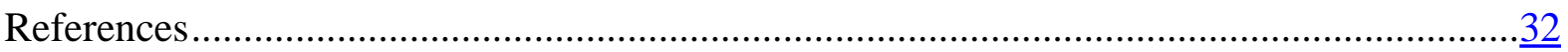

Tables

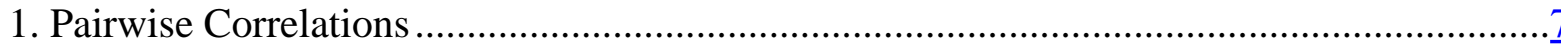

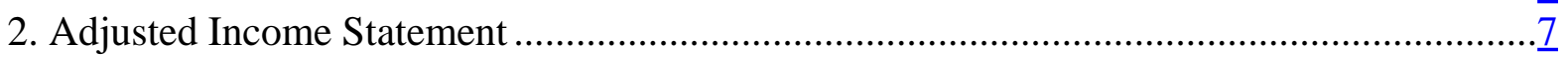

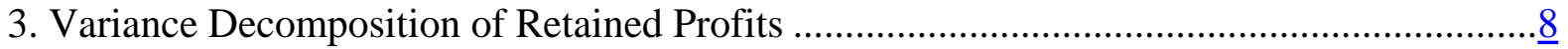

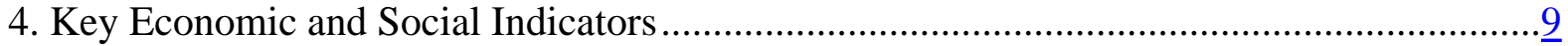

5. Simplifed Balance Sheet .......................................................................................

6a. Income Statement T Tests for Weak Central Banks ..................................................12

6b. Income Statement T Tests for Strong Central Banks..................................................12

7a. Balance Sheet T Tests for Weak Central Banks .......................................................13

7b. Balance Sheet T Tests for Strong Central Banks.......................................................13

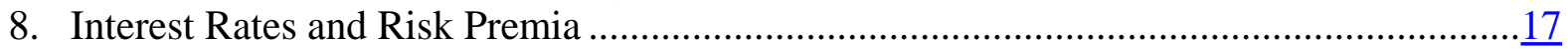

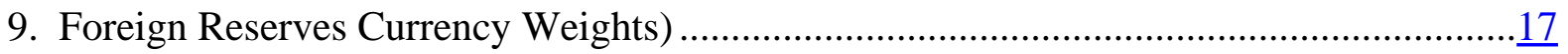

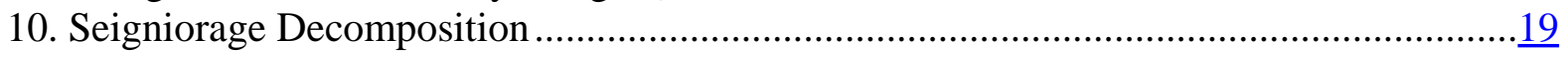


11. Central Banks' Operating Expenditures.....

12. Operating Expenditures: Model Comparison ………….................................................24

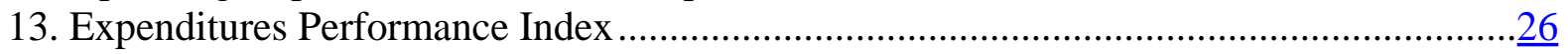

Figures

1. World Inflation and Currency Demand, 1985-2003 ……………………………..............

2. International Reserves, 1985-2004 .........................................................................

3. Countries’ Ranking by Perform Index ............................................................................25

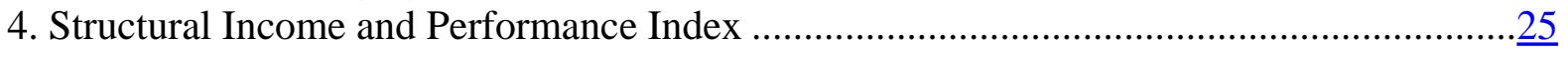

Appendix Table

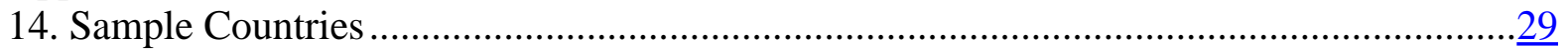




\section{INTRODUCTION}

Central banks' exclusive right to issue currency gives them privileged access to seigniorage, effectively converting them into unregulated monopolies. In the past, the siphoning off of seigniorage to governments (through quasi-fiscal expenditures, profit transfers, or subsidized financing) raised familiar issues of fiscal dominance and inflationary finance. In recent years, substantial efforts have been made to weed out these linkages and enhance central banks' independence by reforming their charters, prohibiting direct financing to governments, and getting rid of quasi-fiscal expenditures. However, keeping the seigniorage inside central banks (to build up their assets, cover the carrying costs of these assets, or cover operating expenses) has brought to the forefront issues of efficiency and governance. Is seigniorage spent "wisely"? Do central banks have sufficient governance standards and safeguards?

These concerns have intensified owing to the deteriorating financial position of many central banks. On the one hand, seigniorage has followed a clear downward trend, reflecting both declining inflation and a declining demand for currency (Figure 1). On the other hand, the carrying cost of foreign reserves has tended to rise, reflecting an expanded accumulation of reserves (Figure 2). Such trends have led to sustained losses and negative capital in many central banks, triggering intense technical and political debates about the need for (as well as extent and modalities of) central bank recapitalizations. ${ }^{2}$

This paper examines how central banks are allocating their shrinking seigniorage. Based on recent central bank financial accounts and interest rate data for a sample of 101 countries, it addresses the following issues:

- $\quad$ How much seigniorage is retained versus transferred? If retained, is seigniorage used to build up the central bank's balance sheet, and, if so, which type of asset; or is it mainly used to cover its operating expenses?

- How can “poor” financial performance be explained? Is it mainly a reflection of central banks' balance sheets or their operating expenditures? Does it mainly reflect structural factors (against which central banks can do little), or does it also reflect poor governance?

- $\quad$ Do central banks that spend more deliver "better quality” services (i.e., better monetary or financial stability)?

There is only scant empirical literature comparing central banks' expenditures. Fry, Goodhart, and Almeida (1996) present a pioneering study in this area, albeit limited to a relatively small sample of 42 central banks and covering only specific aspects of central

\footnotetext{
${ }^{2}$ See Stella (2005) and Ize (2005).
} 
Figure 1. World Inflation and Currency Demand, 1985-2003

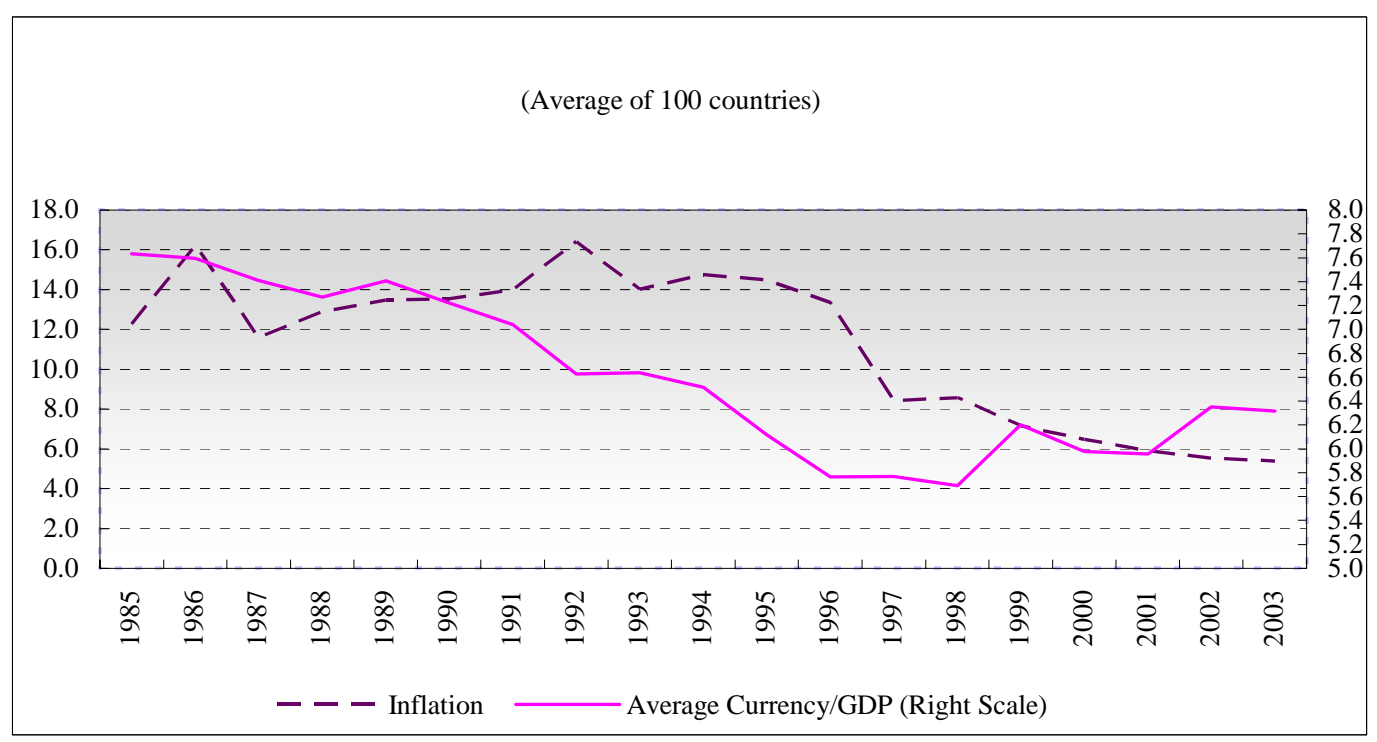

Source: IFS.

Figure 2. International Reserves, 1985-2004* (As percent of currency)

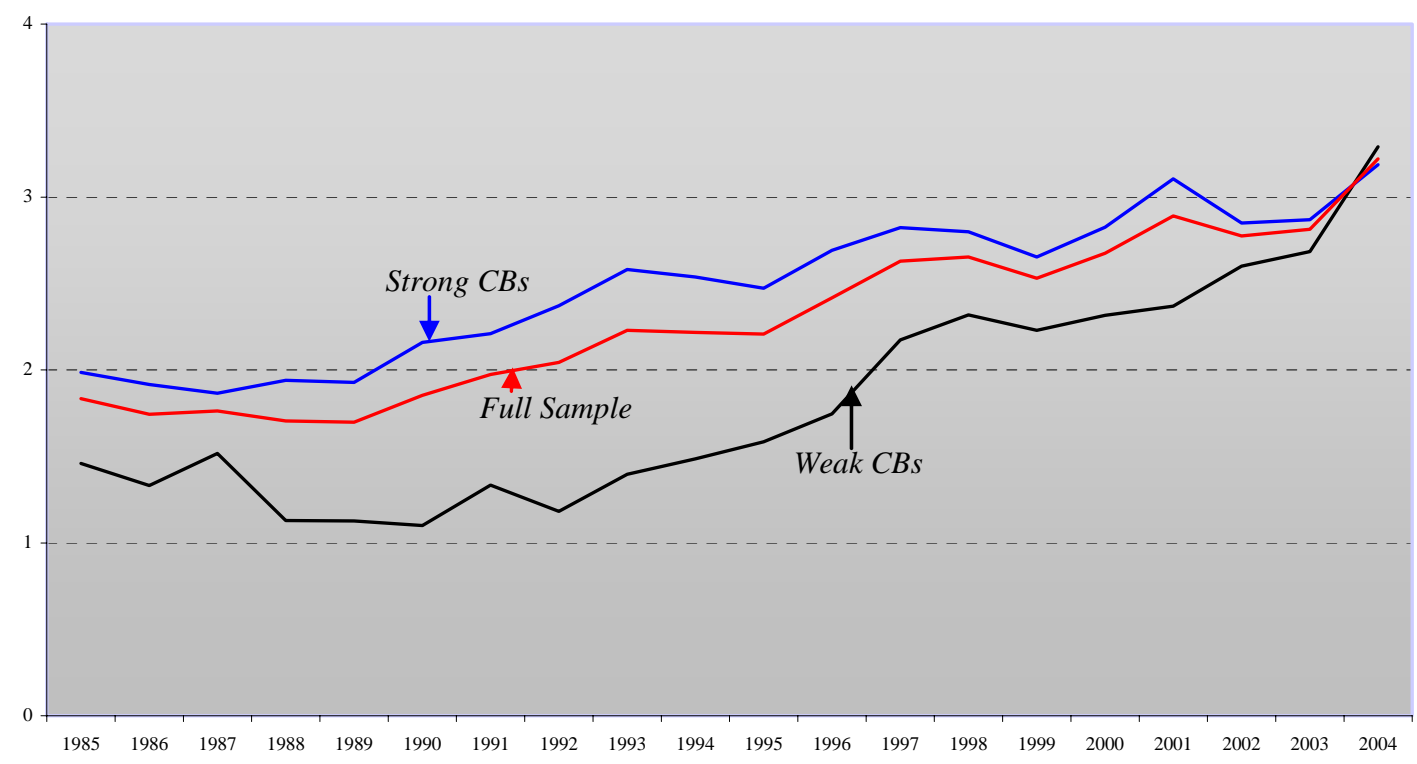

Source: IFS.

*See Section II for the definitions of "strong" and "weak" central banks. 
banks' governance and management, such as the nature of their Board, the number and characteristics of their staff, and the functions they perform. In a more recent study McKinley and Banaian (2005) use a sample of 32 central banks to analyze the efficiency with which “inputs” (labor and capital) are used by central banks to produce “outputs” (a monetary policy quality index and some financial stability indices).

This paper differs from the two papers above in that it relies on published financial accounts and broad accounting concepts, rather than specific management parameters (such as the number or quality of the staff). This allows a more comprehensive coverage in terms of both countries and scope of analysis. It also allows for a more global economic analysis of central bank "behavior," based on broad trends in the data. The paper builds up on a framework presented by Ize (2005), that identifies "structural profits” as a key concept to assess the sustainability of central banks' financial performance and their need for capital. The downside of this broader approach, however, is that the scope of the paper is more limited in terms of defining and measuring central bank efficiency.

Section II describes the accounting data used in the analysis, identifies key linkages, and contrasts the accounts of central banks with strong financial positions with those with weak financial positions. Section III examines how seigniorage is allocated, based on an accounting breakdown of its sources and uses. Section IV examines whether central bank operating expenditures are driven by the demand for central bank services or the availability of seigniorage, and whether there is a measurable link with their overall performance measured in terms of broad macro-financial indicators. Section V concludes by summing up the main findings, briefly discussing some of the key policy implications, and flagging some of the limitations of the paper.

\section{A Cross-Sectional Look at Central Bank Accounts}

\section{The data base}

The first stage of analysis simply aggregates financial accounts across central banks. ${ }^{3}$ To allow for cross-country comparisons, all the data are adjusted by a scale factor. ${ }^{4}$ Currency (rather than GDP) is a natural deflator for central banks. Reflecting the fact that currency is the only fully market-driven source of seigniorage, ${ }^{5}$ one would expect it to play a central role

\footnotetext{
${ }^{3}$ Appendix I describes the data set used in this study.

${ }^{4}$ This scale factor is used to deflate magnitudes across countries, but not across time. For the latter, I use each country’s consumer price index (see below).

${ }^{5}$ Unlike bank deposits (that are, for the most part, mandatory under a reserve requirement regulation) or government deposits (that must be deposited at the central bank under a fiscal agent arrangement), the demand for currency is entirely voluntary.
} 
in central banks' accounts and be highly correlated with key accounting aggregates. As shown in Table 1, this is indeed the case.

Table 1. Pairwise Correlations (all variables in U.S. dollars) ${ }^{6}$

\begin{tabular}{lccccc}
\hline & $\mathbf{O}$ & $\mathbf{S I}$ & $\mathbf{X}_{\mathbf{F}}$ & $\mathbf{X}_{\mathbf{G}}$ & $\mathbf{X}_{\mathbf{B}}$ \\
\hline $\mathbf{C}$ & 0.82 & 0.91 & 0.37 & 0.97 & -0.29 \\
$\mathbf{G D P}$ & 0.84 & 0.91 & 0.45 & 0.84 & -0.23 \\
\hline
\end{tabular}

Sources: IFS and Central Banks’ websites.

\section{Income statements}

Table 2 presents a bird's eye view of income statements for the sample countries, expressed in terms of the sample means (to obtain a measure of dispersion, standard deviations are also reported in parentheses). Valuation changes and all transitory revenues and expenditures are put together and classified as "transitory net income.” The latter includes items such as realized and

Table 2. Adjusted Income Statement (As percent of currency)

\begin{tabular}{lccc}
\hline & Full & Weak Central & $\begin{array}{c}\text { Strong Central } \\
\text { Banks }\end{array}$ \\
\hline & & Banks & \\
Structural income & $\mathbf{6 . 3 2}$ & $\mathbf{3 . 2 6}$ & $\mathbf{1 0 . 6 4}$ \\
Net Interest Margin & 5.80 & -3.35 & 9.92 \\
& $(13.95)$ & $(10.42)$ & $(13.43)$ \\
Other & 0.51 & 0.09 & 0.72 \\
& $(2.39)$ & $(2.83)$ & $(2.16)$ \\
Transitory Income & $\mathbf{0 . 2 5}$ & $\mathbf{5 . 9 2}$ & -2.30 \\
Valuation changes & -0.14 & 4.02 & -2.0 \\
& $(17.07)$ & $(13.27)$ & $(18.32)$ \\
Other & 0.39 & 1.91 & -0.29 \\
& $(4.99)$ & $(6.39)$ & $(4.10)$ \\
Operating Expenditures & $\mathbf{4 . 8 5}$ & $\mathbf{6 . 6 3}$ & $\mathbf{4 . 7 1}$ \\
& $(6.04)$ & $(6.26)$ & $(2.16)$ \\
Transfers & $\mathbf{2 . 5 3}$ & $\mathbf{2 . 2 6}$ & $\mathbf{2 . 6 5}$ \\
& $(5.38)$ & $(8.48)$ & $(3.23)$ \\
Retained Profits & $\mathbf{0 . 8 1}$ & $\mathbf{6 . 2 3}$ & $\mathbf{1 . 6 3}$ \\
& $(18.35)$ & $(17.22)$ & $(18.45)$ \\
\hline
\end{tabular}

Source: Central banks’ websites.

unrealized gains and losses on foreign exchange, securities, and fixed assets; net transfers to and from reserves; provisions and write offs; and other extraordinary gains and losses.

\footnotetext{
${ }^{6}$ See Appendix II for a definition of the variables.
} 
Instead, the net interest margin and the net other structural income (the latter includes net income from commissions and fees and other operating income) are classified as "structural income” (SI).

A few important features are worth noting. As expected, the mean transitory net income is very close to zero while its standard deviation is very large. Indeed, the high standard deviation of retained profits is explained mostly by the high volatility of valuation gains and losses, as illustrated by a variance decomposition (Table 3). Such volatility hinders the yearto-year comparison of central bank performance, as well as its comparison across countries, particularly since many central banks do not clearly distinguish structural versus transitory income in their published accounts. The fact that there is no uniform reporting format further contributes to the opacity of these accounts. Unless efforts are made to clarify and standardize central banks' financial reporting, the switch to international accounting standards, whereby all valuation changes will be charged against profits, could exacerbate this problem. ${ }^{7}$

Table 3. Variance Decomposition of Retained Profits

\begin{tabular}{lcccccc}
\hline & $\begin{array}{c}\text { Net Interest } \\
\text { Margin }\end{array}$ & $\begin{array}{c}\text { Net Other } \\
\text { Structural } \\
\text { Income }\end{array}$ & $\begin{array}{c}\text { Valuation } \\
\text { Gains/Losses }\end{array}$ & $\begin{array}{c}\text { Other Transitory } \\
\text { Net Income }\end{array}$ & $\begin{array}{c}\text { Operating } \\
\text { Expenditure }\end{array}$ & Transfers \\
\hline Full Sample & 0.25 & 0.03 & 0.65 & 0.01 & -0.02 & 0.08 \\
Weak central banks & 0.15 & 0.07 & 0.45 & 0.05 & -0.02 & 0.30 \\
Strong central banks & 0.21 & 0.01 & 0.81 & 0.01 & -0.04 & 0.01 \\
\hline
\end{tabular}

Source: Central banks’ websites.

A second important feature of Table 2 is that central banks' operating expenditures nearly exhaust the interest margin. In view of substantial transfers, retained profits are, on average, negative. Central banks, as a whole, lost capital during the base year used for this study. This is in part the reflection of valuation losses incurred as a result of largely circumstantial exchange rate appreciations against the US dollar (the main reserve currency). However, the fact that central banks' structural profitability (structural income minus operating expenditures) is low (only about 1.5 percent of currency) is also likely to reflect the downward trend in seigniorage.

To delve a bit deeper into these issues, I divide the sample into a subsample of 60 "strong" central banks, those with positive structural pre-transfer profits (defined as the interest

\footnotetext{
${ }^{7}$ The fact that a substantial number of central banks do not publish their income statements, or do not do it in a format that lends itself to meaningful analysis, further underlines the urgent need for greater transparency and accountability.
} 
margin plus the other structural net income minus operating expenditures) and 27 "weak" central banks, those with negative structural profits. Table 2 shows that clear differences arise between the two subsamples. Unlike the weak central banks, the strong central banks indeed accumulated capital.

Remarkably, the poor performance of the weak central banks is explained by both lower structural revenues (they have a negative net interest margin) and higher operating expenditures (they spend over 50 percent as much as strong banks). At first sight, this would suggest that weak performance may be at least partly explained by poor governance. The fact that the average country governance index (measured on the basis of the KKM index) ${ }^{8}$ is lower for weak central bank countries would seem to support this hypothesis (Table 4). However, weak central bank countries are, on average, also structurally different from strong central bank countries. Notwithstanding large standard deviations, that indicate a wide dispersion across the samples, weak central bank countries are, on average, poorer and smaller. Thus, further analysis is warranted to examine to what extent their higher expenditures reflect genuine structural differences, particularly those that might result from increasing returns to scale.

Table 4. Key Economic and Social Indicators

\begin{tabular}{lccc}
\hline & $\begin{array}{c}\text { Full Sample } \\
\text { (87 countries) }\end{array}$ & $\begin{array}{c}\text { Weak Central } \\
\text { Banks } \\
(27 \text { countries })\end{array}$ & $\begin{array}{c}\text { Strong Central } \\
\text { Banks } \\
\text { (60 countries) }\end{array}$ \\
\hline GDP per Capita (USD) & & & \\
Population (millions) & 11139 & 5651 & 13335 \\
& $(13418)$ & $(8388)$ & $(14403)$ \\
Inflation (percent) & 39 & 28 & 43 \\
& $(116)$ & $(47)$ & $(134)$ \\
KKM Index* & 5.19 & 9.49 & 3.46 \\
& $(6.45)$ & $(9.15)$ & $(3.72)$ \\
& 0.39 & -0.01 & 0.54 \\
& $(0.86)$ & $(0.65)$ & $(0.88)$ \\
\hline
\end{tabular}

Sources: IFS; Kaufmann, Kraay, and Mastruzzi (2003).

* A higher index reflects better governance.

It is also remarkable that weak central banks, notwithstanding their negative structural profits, transferred nearly as much as strong central banks. Moreover, unlike for strong central banks, transfers by weak central banks explained a sizable fraction of the variance of their retained profits (Table 3). The opposite is true for the net interest margin: it explains a

\footnotetext{
${ }^{8}$ The KKM Index is calculated as the average of aggregate indicators over six dimensions of governance: Voice, Accountability, Political Stability, Government Effectiveness, Regulatory Quality, and Rule of Law (higher values correspond to better governance). See Kaufmann, Kraay, and Mastruzzi (2003).
} 
higher share of the variance of retained profits for strong central banks than for weak central banks. This strongly suggests that weak central banks, as a group, lack independence. They are being forced to transfer profits which they do not have. As a result, retained profits (what is left after the transfers) for the most part reflect the negative imprint of these transfers.

At the same time, weak central banks benefited from windfall gains, in strong contrast with strong central banks, which incurred valuation losses (as already noted, this resulted from the appreciation of their currency against the U.S. dollar). This contrast can be largely explained by the fact that weak central banks operate under a higher inflation environment, which, by generating a devaluation bias against the dollar (the main reserve currency), enhances seigniorage through systematic valuation gains on dollar assets. Indeed, inflation in the weak central bank sample was nearly three times as high as that in the strong central bank sample (Table 4). This could imply that weak performers make up, at least in part, for their financial difficulties by following looser monetary policies. Alternatively, more inflationary environments allow more room for central bank expenditures and negative structural profitability.

\section{Balance sheets}

To better understand the extent to which the differential performance of weak and strong central banks arises from their balance sheets, Table 5 presents summarized balance sheets for the aggregate sample and the two subsamples. As regards the aggregate sample, some features are worth noticing. In particular, international reserve holdings account for the bulk of central bank assets (over two thirds). This underlines the important role played by central banks in ensuring the external liquidity of their deposits, particularly those of banks (against which central banks have large net liabilities). As a result, only a limited fraction (about onethird) of international reserves are "financed" by fully unremunerated liabilities (currency and capital). This exposes central banks to a large potential "carrying cost" problem when the interest rates on their foreign assets are below those of the liabilities that they back, reflecting maturity, currency, or country risk premia.

Turning to the subsamples, clear differences between strong and weak central banks can be spotted: (i) weak central banks have much higher foreign liabilities; (ii) they have higher net claims on government; (iii) they have both lower claims on (and lower liabilities to) banks; and (iv) they have much less capital. The overall picture that emerges is thus one in which weak central banks are constrained to hold nearly as many international reserves as strong central banks but, in addition, need to provide more financing to governments. Yet, they have less capital and are less profitable. They finance these higher claims through acquiring more foreign debt. ${ }^{9}$ As shown in Ize (2005), this pattern of asset accumulation can undermine the credibility of monetary policy. Unless monetary policy is loosened, negative structural profits

\footnotetext{
${ }^{9}$ Part of this debt is with the IMF, which suggests that, through Fund programs, the IMF may be partly filling up the capitalization gap of weak central banks.
} 
can lead to progressive decapitalizations and increasing debt sustainability problems, particularly if a substantial fraction of claims on government are nonperforming or yield below-market returns.

Table 5. Simplified Balance Sheet (In percent of currency)

\begin{tabular}{lccc}
\hline & Full Sample & $\begin{array}{c}\text { Weak Central } \\
\text { Banks }\end{array}$ & $\begin{array}{c}\text { Strong Central } \\
\text { Banks }\end{array}$ \\
\hline Net Claims & $\mathbf{1 5 4 . 6}$ & $\mathbf{1 0 4 . 2}$ & \\
On foreigners & 277.1 & 192.2 & $\mathbf{1 7 7 . 3}$ \\
Assets & 354.9 & 334.4 & 315.2 \\
Liabilities & -77.9 & -142.2 & 364.2 \\
On Government & 50.7 & 92.2 & -49.0 \\
Assets & 134.1 & 173.8 & 32.0 \\
Liabilities & -83.4 & -81.6 & 116.3 \\
On Banks & -173.1 & -180.3 & -84.3 \\
Assets & 103.2 & 33.2 & -169.9 \\
Liabilities & -276.3 & -213.4 & 134.7 \\
& & & -304.6 \\
Shadow Capital & $\mathbf{1 5 4 . 7}$ & $\mathbf{1 0 4 . 2}$ & \\
Currency & 100.0 & 100.0 & $\mathbf{1 7 7 . 4}$ \\
Capital & 54.7 & 4.2 & 100.0 \\
\hline
\end{tabular}

Source: IFS.

\section{Bivariate statistical analysis}

To complete this preliminary review of the data, I conduct a simple bivariate statistical analysis between all variables in the income and balance sheet accounts, as well as between some selected variables across these accounts. Starting with the income statement (Tables 6a and $6 \mathrm{~b})$, several interesting features emerge:

- $\quad$ Retained profits are very strongly related to transitory net income for both weak and strong banks. This suggests that most central banks avoid transferring their valuation gains and other transitory windfalls. ${ }^{10}$

- $\quad$ There is a strong negative association between retained profits and transfers for the weak central banks. This confirms the finding above that weak central banks are (often) requested to transfer profits that they do not have.

\footnotetext{
${ }^{10}$ In the case of the weak central banks, there exists in fact a surprisingly negative association between transfers and transitory income.
} 
Table 6a. Income Statement T Tests for Weak Central Banks

\begin{tabular}{lrrccr}
\hline & $\begin{array}{r}\text { Operating } \\
\text { Expenditures }\end{array}$ & Transfers & $\begin{array}{c}\text { Retained } \\
\text { Profits }\end{array}$ & $\begin{array}{c}\text { Transitory } \\
\text { Net Income }\end{array}$ & Capital \\
\hline Net Interest Margin & $2.3^{* *}$ & -1.73 & $2.75^{* *}$ & $1.88^{*}$ & 0.95 \\
Operating Expenditures & & 0.09 & -0.06 & 0.71 & 1.05 \\
Transfers & & & $-6.79^{* *}$ & $-3.66^{* *}$ & 1.17 \\
Retained Profits & & & & $10.82^{* *}$ & -1.23 \\
Transitory Net Income & & & & & -0.71 \\
\hline
\end{tabular}

Table 6b. Income Statement T Tests for Strong Central Banks

\begin{tabular}{lccccr}
\hline & $\begin{array}{c}\text { Operating } \\
\text { Expenditures }\end{array}$ & Transfers & $\begin{array}{c}\text { Retained } \\
\text { Profits }\end{array}$ & $\begin{array}{c}\text { Transitory } \\
\text { Net Income }\end{array}$ & Capital \\
\hline Net Interest Margin & $5.32^{* *}$ & 0.68 & $2.66 * *$ & -1.44 & 1.65 \\
Operating Expenditures & & 0.23 & 1.28 & 0.39 & 0.47 \\
Transfers & & & -0.53 & $2.03^{* *}$ & 1.01 \\
Retained Profits & & & $9.72^{* *}$ & 1.26 \\
Transitory Net Income & & & & & 1.11 \\
\hline
\end{tabular}

Sources: IFS and central banks' websites.

* 90 percent significance level.

** 95 percent significance level.

- $\quad$ Operating expenditures are positively related to the net interest margin in all central banks, but the link is much stronger in the strong central banks. This suggests that strong central banks face soft budget constraints that allow the most profitable ones to raise their expenditures. For weak central banks, the weaker link between operating expenditures and net interest margins suggests that their attempts to restrain their operating expenditures are only half-hearted and meet limited success. High margins tend to translate into higher operating expenditures; low (or negative) margins primarily translate into low (or negative) profits.

- Interestingly, there appears to be no strong link between capital and structural profitability, or any other key income concept (albeit the " $t$ " statistic between the interest margin and capital is mildly significant for the strong central banks). This could be interpreted as an indication that central banks primarily transfer or spend their profits, but do not systematically retain them to increase their capital. ${ }^{11}$

\footnotetext{
${ }^{11}$ It is somewhat puzzling, however, that higher losses in weak central banks do not seem to be associated (at least at a cross-country level) with lower capital. One possible explanation is that banks with declining capital are eventually recapitalized.
} 
Similar tests for the balance sheet account (Tables 7a and 7b) show the following results:

Table 7a. Balance Sheet T Tests for Weak Central Banks

\begin{tabular}{|c|c|c|c|c|c|c|c|c|}
\hline & $\begin{array}{l}\text { Foreign } \\
\text { Assets }\end{array}$ & $\begin{array}{l}\text { Claims } \\
\text { on Gvt }\end{array}$ & $\begin{array}{l}\text { Claims } \\
\text { on Banks }\end{array}$ & $\begin{array}{c}\text { Foreign } \\
\text { Liabilities }\end{array}$ & Currency & $\begin{array}{c}\text { Bank } \\
\text { Deposits }\end{array}$ & $\begin{array}{c}\text { Gvt } \\
\text { Deposits }\end{array}$ & Capital \\
\hline Structural profits & $-1.73^{*}$ & $-2.09 * *$ & $1.84 *$ & $-1.92 *$ & $1.79 *$ & -0.42 & $-3.75^{* *}$ & 0.48 \\
\hline Foreign assets & & 0.07 & -0.41 & 0.12 & $1.91^{*}$ & 2.54 & $3.78 * *$ & 1.32 \\
\hline Claims on gvt & & & -0.21 & $10.44 * *$ & 0.24 & 1.04 & 0.08 & $1.9 *$ \\
\hline Claims on banks & & & & -0.53 & -0.02 & $3.13^{* *}$ & -0.91 & 1.34 \\
\hline Foreign liabilities & & & & & -0.32 & 0.31 & -0.37 & 1.57 \\
\hline Currency & & & & & & 0.94 & -1.17 & -0.19 \\
\hline Bank deposits & & & & & & & 0.49 & 0.83 \\
\hline Gvt deposits & & & & & & & & 1.15 \\
\hline
\end{tabular}

Table 7b. Balance Sheet T Tests for Strong Central Banks

\begin{tabular}{|c|c|c|c|c|c|c|c|c|}
\hline & $\begin{array}{l}\text { Foreign } \\
\text { Assets }\end{array}$ & $\begin{array}{l}\text { Claims } \\
\text { on Gvt }\end{array}$ & $\begin{array}{l}\text { Claims } \\
\text { on Banks }\end{array}$ & $\begin{array}{l}\text { Foreign } \\
\text { Liabilities }\end{array}$ & Currency & $\begin{array}{c}\text { Bank } \\
\text { Deposits }\end{array}$ & $\begin{array}{c}\text { Gvt } \\
\text { Deposits }\end{array}$ & Capital \\
\hline Structural profits & 1.53 & $3.11 * *$ & -0.38 & $2.71^{* *}$ & -0.01 & -0.05 & 2.45 & 1.16 \\
\hline Foreign assets & & -0.91 & -1.31 & -0.008 & $2.63^{* *}$ & -0.55 & $10.9 * *$ & $8.51^{* *}$ \\
\hline Claims on gvt & & & -0.09 & $10.3^{* *}$ & 0.82 & 0.13 & 1.09 & -0.15 \\
\hline Claims on banks & & & & -0.05 & -0.67 & $26.26 * *$ & -0.31 & -0.45 \\
\hline Foreign liabilities & & & & & 0.62 & -0.15 & 0.88 & 0.04 \\
\hline Currency & & & & & & -0.36 & 0.47 & 0.74 \\
\hline Bank deposits & & & & & & & 0.16 & -0.56 \\
\hline Gvt deposits & & & & & & & & $6.67 * *$ \\
\hline
\end{tabular}

- $\quad$ Both weak and strong central banks exhibit a very strong positive link between claims on government and foreign liabilities. This suggests that central banks play an important role as financial intermediaries, borrowing funds abroad and on-lending them to governments.

- $\quad$ There is also a substantial link going in the opposite direction: central banks invest abroad part of the funds they receive as government deposits. This link is stronger for the strong banks.

- $\quad$ Central banks also intermediate funds for banks domestically. Those that have higher bank deposits also provide higher financing to banks. This link is extremely strong in the case of the strong banks. There are two possible explanations, one of a budgetary 
nature and the other of a monetary nature. By imposing (unremunerated) reserve requirements on banks and on-lending these funds back to banks through credit auctions or other liquidity injection instruments, central banks gain a spread that contributes to their profitability. At the same time, maintaining commercial banks liquidity short allows central banks to ensure better control on interest rates. The fact that structural profits are unrelated to bank deposits would suggest that the monetary explanation is more plausible.

- $\quad$ Structural profits are negatively related to both claims on government and government deposits in the weak central banks. In strong central banks, the opposite holds. In addition, the strong banks that have more government deposits also have higher capital. This suggests that being a banker to government is "good business" for strong central banks, and "bad business" for weak central banks. In the former case, central banks gain from the spread. In the latter case, central banks probably lose from the fact that many of their assets on government are nonperforming. In addition, central banks that are more strongly linked to governments are more likely to be requested to assume costly quasi-fiscal responsibilities. This supports the argument that the low profitability in weak central banks at least in part reflects their limited independence and their use by governments as sources of financing and revenue.

- $\quad$ More capitalized central banks have higher foreign assets. However, this is true only for strong central banks. This suggests that allowing profitable central banks to retain a higher share of their profits would primarily result in a higher accumulation of foreign reserves, rather than of domestic assets.

\section{SOURCES AND USES OF SEIGNIORAGE}

\section{The analytical framework}

After this preliminary analysis of the data, I now use an accounting decomposition to examine key differences between strong and weak central banks as regards the sources and uses of seigniorage. Without loss of generality, a central bank's balance sheet can be expressed as

$$
C+K=E X_{F}+X_{B}+X_{G}
$$

where $C$ is currency issued, $K$ is capital, $X_{F}, X_{B}$, and $X_{G}$ are the net claims on the foreign sector, banks (and the private sector), and the public sector, respectively, and $E$ is the nominal exchange rate against the U.S. dollar. ${ }^{12}$ Alternatively, domestic claims may be expressed as

\footnotetext{
${ }^{12}$ I assume that domestic claims are all denominated in local currency.
} 


$$
X_{B}+X_{G}=B-D
$$

where $B$ and $D$ are net interest-bearing assets and non-interest-bearing liabilities, respectively.

Defining $R$ and $R^{*}$ as the nominal and foreign (US) interest rate, $r$ and $r^{*}$ as the real domestic and foreign rates, and $\pi$ and $\pi^{*}$ as the domestic and US rate of inflation, the central bank's income statement can be written as

$$
\Omega^{C}=\dot{K}=\left(R^{*}+\frac{\dot{E}}{E}\right) E X_{F}+R B-Z-O-T
$$

where $\Omega^{C}$ is the International Accounting Standards (IAS) definition of central bank profits (inclusive of valuation gains and losses), $O$ is operating expenditures, $T$ is transfers to the treasury, and $Z$ is other net exceptional expenditures (such as provisions and write-offs on bad assets).

Replacing $B$ in (3), using (1) and (2), (3) can be rewritten as

$$
\Omega^{C}=\left(R^{*}+\frac{\dot{E}}{E}\right) E X_{F}+R\left(C+D+K-E X_{F}\right)-Z-O-T \text {. }
$$

Replacing $\Omega^{C}$ by $\dot{K}$, and differentiating (1), equation (4) can be written:

$$
R(C+D+K)=\Phi E X_{F}+\left(E \dot{X}_{F}+\dot{X}_{G}+\dot{X}_{B}-\dot{C}\right)+O+Z+T
$$

where $\Phi=R-R^{*}$ is the nominal interest rate premium.

Finally, correcting this last expression for both domestic and foreign inflation (i.e., expressing it in real terms), leads, using (1), to:

$$
R(c+d+k)=(\varphi+\pi) E X_{F}+E\left(X_{F}-\pi^{*} X_{F}\right)+\left(X_{G}-\pi X_{G}\right)+\left(X_{B}-\pi X_{B}\right)-(C-\pi C)+(o+z+t),
$$

where $\varphi=r-r^{*}$ and $e$ are the real interest rate premium and the real exchange rate, respectively. Assembling all the domestic inflation terms, and using (1), this can also be written:

$$
R(c+d+k)=\left(\varphi e x_{F}+\pi k\right)+\left(e \dot{x}_{F}+\dot{x}_{G}+\dot{x}_{B}-\dot{c}\right)+(o+z+t)
$$


where the lower-case letters stand for domestic price-deflated magnitudes, in the case of domestic-currency-denominated variables, and foreign price-deflated magnitudes, in the case of foreign-currency-denominated variables.

The left hand side of this equation indicates that seigniorage originates from three sources: (i) currency; (ii) net nonremunerated liabilities to banks and the public sector; and (iii) capital. The right-hand side defines the uses of seigniorage and can also be divided up into three terms: (i) balance sheet costs (the terms in the first parentheses), namely the carrying cost of international reserves, and the user cost of capital; (ii) the real accumulation of capital, which can take the forms on increases in real claims on foreigners (i.e., adjusted for foreign inflation), or increases in net real claims on domestic residents (i.e., adjusted for domestic inflation); and (iii) flow expenditures, namely operating expenditures, (net) exceptional expenditures, and transfers to the shareholder.

An alternative presentation considers currency as "shadow” capital: ${ }^{13}$

$$
R(c+d+k)+\dot{c}=\left(\varphi e x_{F}+\pi k\right)+\left(e x_{F}+\dot{x}_{G}+\dot{x}_{B}\right)+(o+z+t)
$$

In this case, currency provides seigniorage through both the implied nominal return on currency balances and the increase in real demand for currency. On the right hand side, the second term between parentheses, the total net asset accumulation, accounts for net capital accumulation under the broader definition of capital.

Since $D$ is not known, the term $R D$ is obtained as a residual. A positive $R D$ should thus indicate that the imputed interest income originating from unremunerated deposits at the central bank dominates any imputed interest cost arising from nonperforming assets.

\section{Interest rates and risk premia}

Interest rates are obtained from yields on treasury bonds, when available. In those cases where only rates on short-term public debt (treasury bills) are available, the bond rate is obtained by adding to the bill rate the average spread between the bond rate and the bill rate for those countries where both data are available.

Table 8 sums up the interest rate data. As would be expected, the nominal interest rate is higher in weak central bank countries, reflecting higher inflation. Similarly, inflation and the nominal interest rate (hence nominal premia) rise as per capita income declines. In real terms, however, there is no significant difference between strong central banks and weak central banks.

\footnotetext{
${ }^{13}$ See Stella (1997).
} 
The fact that weak central banks do not appear to be penalized (i.e., there is no clear market discipline) is puzzling. While it is true that central banks can eventually clean up their financial position through a burst of inflation, one would nonetheless expect such a threat to be reflected in a higher risk premium. One possible explanation as to why this does not appear to be the case may be that most interest rates used in this study are associated with treasury liabilities, rather than central bank liabilities. Beyond such data limitations, there are three potential explanations: (i) the threat of future inflation is too diffuse in time to have a significant impact on current rates; (ii) weak central banks are expected eventually to be recapitalized by their shareholder (i.e., they benefit from an implicit government guarantee); or (iii) central banks' financial condition is generally not well perceived in the market place, perhaps in part due to the opacity of their accounts and the fact that their profitability follows different rules and dynamics from those of commercial banks.

Table 8. Interest Rates and Risk Premia

\begin{tabular}{lccc}
\hline & Full & Weak & Strong Central \\
Sample & Central Banks & Banks \\
\hline Nominal Rate & 9.31 & 13.05 & 7.73 \\
Inflation & 5.16 & 9.22 & 3.43 \\
Nominal Premium & 7.21 & 10.95 & 5.62 \\
Real Rate & 3.99 & 3.72 & 4.10 \\
Real Premium & 4.15 & 3.88 & 4.26 \\
\hline
\end{tabular}

Source: IFS.

\section{Valuation adjustments}

To obtain the real changes in net foreign claims (i.e., the change in foreign claims adjusted for exchange rate valuation effects and foreign inflation), assumptions about the currency composition of international reserves are needed. As central banks do not make their foreign reserve management policies (nor debt composition) public, I use, based on a mix of expert opinion and a recent study by Eichengreen and Mathieson (2000), the weights shown in Table 9.

Table 9. Foreign Reserves Currency Weights (In percent)

\begin{tabular}{lccc}
\hline & Dollar & Euro & Yen \\
\hline Euro Countries & 70 & & 30 \\
U.S. & 50 & 50 \\
All other countries & 70 & 25 & 5 \\
\hline
\end{tabular}

Source: Author’s estimates. 
To estimate exchange rate valuation adjustments, I use the average of two polar opposite methods. The first method calculates price adjustments based on beginning-of-year balances and volume changes based on end-of-year balances. The second method does the opposite. ${ }^{14}$ As shown in Appendix II, both methods provide a decomposition of price and quantity effects that ensures consistency between the income statement and the balance sheet.

To ensure similar consistency, price adjustments (to deflate nominal magnitudes into real magnitudes) are carried out following the same methodology. I use each country's CPI to obtain domestic inflation, and the reserve countries' CPIs (with the weights indicated in Table 9) to obtain foreign inflation.

\section{Results}

Table 10 shows the results of the seigniorage decomposition. For the sample as a whole, the main highlights are as follows:

- $\quad$ On the source side of seigniorage, it is remarkable that the unremunerated deposits in central banks produce more seigniorage than currency. This underlines central banks' high dependence on non-market-based income.

- $\quad$ However, on the user side of seigniorage, balance sheet costs, mainly the carrying cost of international reserves, are also by far the dominating element, accounting for nearly half of all seigniorage use. This suggests that the cost of the "liquidity service" provided by central banks through their international reserve holdings is approximately covered by the potential users of such services (the government and the financial system). While there is no assurance that the level (and quality) of the service provided is really that "demanded" by the users and that the cost sharing between users is fair, the fact that on average users pay the associated cost is on the whole reassuring.

- $\quad$ Operating expenditures account for a substantial additional chunk of seigniorage use (about 35 percent), leaving only modest residuals available for capital accumulation (about 18 percent) and dividend transfers to the shareholder (about 12 percent).

- $\quad$ Remarkably, international reserve accumulation accounts for the bulk of net asset accumulation (this observation, based on flows, confirms the earlier similar observation, which was based on stocks). Instead, there is a positive but small

\footnotetext{
14 The first method assumes that interest accrues only on initial balances; the second method assumes it applies fully to final balances.
} 
Table 10. Seigniorage Decomposition

\begin{tabular}{lccc}
\hline & $\begin{array}{c}\text { Full } \\
\text { Sample }\end{array}$ & $\begin{array}{c}\text { Weak Central } \\
\text { Banks }\end{array}$ & $\begin{array}{c}\text { Strong Central } \\
\text { Banks }\end{array}$ \\
\hline Seigniorage & $\mathbf{1 9 . 9 7}$ & $\mathbf{1 4 . 6 6}$ & $\mathbf{2 2 . 3 6}$ \\
$\mathrm{Rc}$ & 8.64 & 12.09 & 7.09 \\
$\mathrm{Rk}$ & 2.30 & -1.19 & 3.87 \\
$\mathrm{Rd}$ & 9.03 & 3.76 & 11.40 \\
\hline Balance sheet costs & $\mathbf{9 . 4 0}$ & $\mathbf{1 0 . 7 4}$ & $\mathbf{8 . 7 9}$ \\
$\phi \mathrm{e}_{\mathrm{F}}$ & 8.16 & 10.47 & 7.11 \\
$\pi \mathrm{k}$ & 1.24 & 0.27 & 1.68 \\
\hline Expenditure flows & $\mathbf{6 . 9 9}$ & $\mathbf{6 . 9 8}$ & $\mathbf{7 . 0 0}$ \\
$\mathrm{O}$ & 4.85 & 6.63 & 4.06 \\
$\mathrm{Z}$ & -0.39 & -1.91 & 0.29 \\
$\mathrm{~T}$ & 2.53 & 2.26 & 2.65 \\
\hline Capital Accumulation & $\mathbf{3 . 5 8}$ & $-\mathbf{3 . 0 5}$ & $\mathbf{6 . 5 7}$ \\
$\mathrm{e} \Delta \mathrm{x}_{\mathrm{F}}$ & 20.58 & 26.84 & 17.77 \\
$\Delta \mathrm{x}_{\mathrm{G}}$ & 4.28 & -13.21 & 12.15 \\
$\Delta \mathrm{x}_{\mathrm{B}}$ & -14.96 & -10.11 & -17.14 \\
$\Delta \mathrm{c}$ & -6.32 & -6.57 & -6.21 \\
\hline
\end{tabular}

Sources: IFS and central banks’ websites.

accumulation of net claims on government, and a large reduction of claims on banks. $^{15}$

Results for the two subsamples show very marked differences:

- $\quad$ Notwithstanding equivalent real risk premia and lower net foreign reserves, weak central banks face higher carrying costs of foreign liquidity than strong central banks. This surprising result derives from the fact that risk premia and net foreign assets are positively correlated for weak central banks, and negatively correlated for strong central banks. For the latter, the negative correlation could reflect the fact that countries with higher international reserves are more stable, hence pay a lower cost of funds. For the former, the causality could flow the other way; countries which are less stable (hence pay higher premia) increase their reserves in an attempt to increase their

${ }^{15}$ While this could imply that much of the accumulation of international reserves is systematically covered by increases in bank deposits (which would be consistent with central banks offering banks a liquidity service on their deposits), the bivariate tests do not support this view. 
stability and reduce their cost of funds. This interpretation is consistent with the fact that, as was already apparent in Figure 2, weak central banks accumulate foreign assets at a much higher rate than strong central banks.

- $\quad$ At the same time, as already noted above, weak central banks are burdened with much higher operating expenditures than strong central banks and have roughly equivalent transfers.

- $\quad$ Yet, most remarkably, despite much higher inflation (hence higher nominal interest rates and, consequently, a much higher seigniorage on currency) and higher bank and government deposits, weak central banks generate a much lower total seigniorage than strong central banks. This surprising result follows from the fact that the higher seigniorage on currency is more than offset by much lower seigniorage on capital and other non-interest-bearing liabilities.

- $\quad$ The lower (negative) capital could be a reflection of a gradual erosion of the central banks' revenue base, following persistently negative profits. While such an interpretation could not be confirmed by the bivariate statistical analysis conducted above, it is consistent with the results in the next section, which show that weak central banks lose capital in real terms, i.e., after adjusting for inflation.

- In turn, the lower $R d s$ can reflect a higher proportion of remunerated deposits or nonperforming assets. Assuming no nonperforming assets, the comparison of $R d$ and $R c$, based on sample averages, indicates that up to 84 percent of deposits at the weak central banks are being remunerated (against only 32 percent for the strong central banks). Alternatively (and perhaps more realistically), assuming no remunerated deposits leads one to conclude that only 10 percent of weak central banks' assets on government and banks are remunerated (against 66 percent for strong central banks).

- $\quad$ Faced with such seigniorage shortfalls, the adjustment variable is real capital accumulation. In sharp contrast with strong central banks that accumulate substantial (real) capital, weak central banks lose capital. This rather bleak conclusion only holds, however, under a strict definition of capital. Under a broader definition (that includes currency), weak central banks, as a group, still accumulate some capital (or at least did so in the year this study is based on). While this accumulation is of course much lower than that in the strong central banks, it might be sufficient to stave off a downward spiral into debt unsustainability. This would seem to be consistent with the earlier finding that weak central banks do not seem to face substantial penalties as regards interest rate premia.

- $\quad$ It is also noteworthy that weak central banks are able to accumulate international reserves despite their weak financial condition, due to a high accumulation of 
liabilities with government. ${ }^{16}$ This highlights the fact that, as already noted, weak central banks are highly dependent on their governments and "bank" for them rather than for their commercial banks. At the same time, however, the sharp contrast between weak central banks and strong central banks as regards the direction of seigniorage flows is remarkable and somewhat counterintuitive. Governments end up benefiting from seigniorage proceeds only when their central banks are strong.

- $\quad$ Finally, it is also worth noting that while strong central banks have nearly insignificant exceptional expenditures, weak central banks report significant exceptional incomes. While such incomes are difficult to pin down and might be mostly circumstantial, the possibility exists that they might reflect (at least in some cases) efforts to dress up the central banks' accounts and limit their reported losses through "creative accounting."

\section{What DETERMINES CENTRAL BANKS’ OPERATING EXPENDITURES?}

\section{Are central bank expenditures demand or supply driven?}

I will now focus on the analysis of central bank operating expenditures, which should be related to the amount of services central banks provide and the price of these services. Such services can be classified into two broad categories; those directly related with monetary management (price stability and money market development), and those related to financial system stability and development (supervision and payments, including the provision of currency).

When central banks face a soft revenue constraint (which should be the case for strong central banks), one would expect the provision of central bank services to be determined strictly from the demand side (supply accommodating demand). Demand should rise with country size (possibly with increasing returns), per capita GDP (assuming central bank services are not inferior goods), the size of the financial sector, and the scope of central banks' responsibilities (in particular, whether they are responsible for financial supervision). When central banks face a harder revenue constraint, one would expect supply factors to dominate (demand accommodating supply). Relevant supply factors should include variables that determine the availability of seigniorage (such as inflation, currency in circulation, or currency growth), or the cost of central bank services (mostly the wage level of central bank staff). In the latter case, variables that determine how wisely the seigniorage may be used (such as governance indices) could also affect the outcome.

The very high (82 percent) correlation between currency issued and central banks' operating expenditures would suggest, at first sight, that supply-side effects might dominate (Table 1).

\footnotetext{
${ }^{16}$ This flow observation confirms the observation made earlier based on the bivariate statistical analysis of stocks.
} 
To test whether this is indeed the case and whether some central banks may be affected by "hard" revenue constraints, I compare the following non-nested models. On the demand side, regressors include population, per capita GDP, M2 over GDP (all variables in logs), and a multiplicative dummy for central banks that are responsible for banking supervision. On the supply side, regressors include (the log of) currency in circulation, the KKM governance index, and the average inflation rate over the past 10 years.

Results are reported in Table 11. Neither the financial depth variable in the demand model nor the wage level or inflation variables in the supply model are significant. Both models give otherwise satisfactory results, with all variables having the appropriate signs. In the demand model, there are very clear size and wealth effects. However, there are also clear increasing returns, as a 10 percent increase in country size or per capita income is reflected in only a 7.5 percent or 5.8 increase, respectively, in operating expenditures. This confirms the earlier finding that central banks in the smaller and poorer countries are more likely to struggle financially than those in large, wealthier countries, reflecting the fixed costs of central banking. Similar increasing returns are present in the supply model, with a 10 percent increase in currency issued translating into only a 7 percent increase in operating expenditures.

It is also noteworthy that the provision of supervisory services, while significant, has only a modest impact on central banks' operating expenditures, increasing them by less than 2 percent. Similarly, the governance variable has a significant but modest impact, with an improvement in the KKM index from the worst to the best country in the sample reducing central banks' operating expenditures by slightly over 1 percent.

To test whether there is a substantial difference between the two groups of central banks, the two models are estimated for each subsample. While financial depth has a significant impact on the operating expenditures of weak central banks but not on those of the strong central banks, other effects are very similar.

The results of the model comparison for the aggregate sample, using the Davidson and Mackinnon's J-statistics for non-nested models, appear in Table $12 .{ }^{17}$ They indicate that the demand model dominates the supply model, which is consistent with the numerical dominance of the strong central banks in the overall sample. This suggests therefore that central banks' operating expenditures are driven, overall, by a soft budget constraint.

${ }^{17}$ This test compares the relative significance of the predicted values of each model when introduced as a regressor in the other model. See Davidson and MacKinnon (1981). 
Table 11. Central Banks' Operating Expenditures

\begin{tabular}{|c|c|c|c|c|c|c|c|c|c|}
\hline \multirow[b]{2}{*}{ Variables } & \multicolumn{3}{|c|}{ Full Sample } & \multicolumn{3}{|c|}{ Strong Central Banks } & \multicolumn{3}{|c|}{ Weak Central Banks } \\
\hline & Demand & Supply & Red. form & Demand & Supply & Red. form & Demand & Supply & Red. Form \\
\hline Log (population) & 0.76 & & 0.61 & $\begin{array}{c}0.74 \\
(20.45)^{*}\end{array}$ & & 0.55 & 0.86 & & 0.86 \\
\hline & $(22.20)^{* *}$ & & $(7.24)^{* *}$ & * & & $(5.43)^{* *}$ & (12.19)** & & $(3.30)^{* *}$ \\
\hline $\log (\mathrm{GDP} / \mathrm{PC})$ & 0.62 & 0.068 & 0.58 & $\begin{array}{c}0.61 \\
(12.94)^{*}\end{array}$ & & 0.51 & 0.57 & & 0.75 \\
\hline & $(14.93)^{* *}$ & $(0.71)$ & $(5.67)^{* *}$ & $*$ & & $(3.88)^{* *}$ & $(7.40)^{* *}$ & & $(3.12)^{* *}$ \\
\hline Bank Supervision & 0.01 & & 0.01 & 0.008 & & 0.007 & 0.03 & & 0.03 \\
\hline & $(2.26)^{*}$ & & $(1.93)^{*}$ & (1.05) & & $(0.95)$ & $(1.83)^{*}$ & & (1.41) \\
\hline $\log (\mathrm{M} 2 / \mathrm{GDP})$ & $\begin{array}{l}-0.005 \\
(-0.16)\end{array}$ & & & $\begin{array}{c}0.0004 \\
(0.01)\end{array}$ & & & $\begin{array}{c}0.78 \\
(3.3)^{* *}\end{array}$ & & \\
\hline Log (Currency) & & $\begin{array}{c}0.67 \\
(19.52)^{* *}\end{array}$ & $\begin{array}{c}0.15 \\
(1.98)^{*}\end{array}$ & & $\begin{array}{c}0.67 \\
(18.23)^{* *}\end{array}$ & $\begin{array}{c}0.19 \\
(2.07)^{*}\end{array}$ & & $\begin{array}{c}0.70 \\
(7.12)^{* *}\end{array}$ & $\begin{array}{c}-0.05 \\
(-0.21)\end{array}$ \\
\hline KKM & & $\begin{array}{c}-0.41 \\
(-2.96)^{* *}\end{array}$ & $\begin{array}{c}-0.22 \\
-(1.34)\end{array}$ & & $\begin{array}{c}-0.09 \\
(-0.46)\end{array}$ & $\begin{array}{c}-0.16 \\
(-0.95)\end{array}$ & & $\begin{array}{c}-0.41 \\
(-1.23)\end{array}$ & $\begin{array}{l}-0.012 \\
(-0.05)\end{array}$ \\
\hline Adjusted R-squared & 0.54 & 0.83 & 0.88 & 0.89 & 0.85 & 0.90 & 0.91 & 0.81 & 0.87 \\
\hline S.E. of regression & 0.54 & 0.63 & 0.53 & 0.51 & 0.59 & 0.49 & 0.46 & 0.69 & 0.58 \\
\hline Sum squared resid & 26.91 & 36.95 & 25.32 & 16.40 & 22.39 & 15.06 & 4.87 & 10.90 & 7.03 \\
\hline Log likelihood & -75.46 & -90.39 & -72.24 & -48.33 & -59.07 & -45.39 & -15.24 & -26.07 & -20.14 \\
\hline DW & 2.00 & 1.92 & 2.03 & 2.28 & 2.00 & 2.21 & 2.31 & 2.24 & 2.22 \\
\hline Mean dependent var & 18.00 & 18.00 & 18.00 & 17.97 & 17.97 & 17.97 & 18.05 & 18.09 & 18.09 \\
\hline S.D. dependent var & 1.54 & 1.54 & 1.54 & 1.54 & 1.54 & 1.54 & 1.56 & 1.57 & 1.57 \\
\hline F-statistic & 171.08 & 156.67 & 142.49 & 141.05 & 134.12 & 122.09 & 72.23 & 37.67 & 34.32 \\
\hline Prob(F-statistic) & 0.00 & 0.00 & 0.00 & 0.00 & 0.00 & 0.00 & 0.00 & 0.00 & 0.00 \\
\hline
\end{tabular}

A reduced-form equilibrium model that combines and retains all significant demand and supply factors is finally estimated (Table 11). Based on the residuals of the equilibrium model, I derive an index of "relative performance", $p_{i}$, for central bank i as

$$
p_{i}=100\left(e^{\delta_{i}}-1\right) \text {, }
$$

where $\delta_{i}$ is the residual of the reduced form regression. Thus, $p_{i}$ is the percentage over-or underspending of central bank $i$ compared to its peers.

The performance index, which is shown in Figure 3, indicates that differences in performance are very large. The best performer spends over three times less than the group average, while the worst performer spends over five times more than the average. By itself, this is already a clear indication that central banks face soft budget constraints and may face severe governance issues. 
Table 12. Operating Expenditures: Model Comparison

\begin{tabular}{lcc}
\hline Variables & $\begin{array}{c}\text { Model 1 } \\
\text { (Demand) }\end{array}$ & $\begin{array}{c}\text { Model 2 } \\
\text { (Supply) }\end{array}$ \\
\hline Log (population) & 0.59 & \\
Log (GDP/PC) & $(6.07)^{* *}$ & \\
Bank Supervision & 0.48 & \\
& $(5.75)^{* *}$ & \\
Log (Ô) (Model 2) & 0.015 & \\
& $(2.03)^{* *}$ & \\
Log (currency) & 0.25 & 0.16 \\
& $(1.90)^{*}$ & $(1.90)^{*}$ \\
KKM & & -0.09 \\
& & $(1.3)$ \\
Log (Ô) (Model 1) & & 0.79 \\
C & & $(6.42)^{* *}$ \\
& -0.09 & 0.26 \\
Adjusted R-squared & $(0.13)$ & $(0.35)$ \\
S.E. off regression & & \\
Log likelihood & 0.88 & 0.88 \\
DW & 0.53 & 0.53 \\
\hline
\end{tabular}

This conclusion is further supported by the fact that weak central banks tend to have lower expenditure performance indices. This can be seen in Figure 3, where weak central banks are grouped on the right hand side of the chart. It is similarly apparent from a scatter diagram between the expenditure performance index and the ratio of structural profitability to currency (Figure 4) that the central banks that overspend tend to be least profitable. This clearly points in the direction of weak governance. With strong governance, financially weaker central banks should underspend (rather than overspend) as a result of efforts to restrain their operating expenditures.

\section{Are countries getting their money's worth in central banking services?}

Determining whether central banks' operating expenditures are justified based on results is obviously a complex and potentially contentious matter. This paper limits itself to providing very preliminary results, based on a simple cross-country regression of central banks' expenditure performance index against basic indicators of macro-financial stability. The 
Figure 3. Countries’ Ranking by Performance Index (In percent)



*Weak Central Banks

Figure 4. Structural Income and Performance Index (In percent)

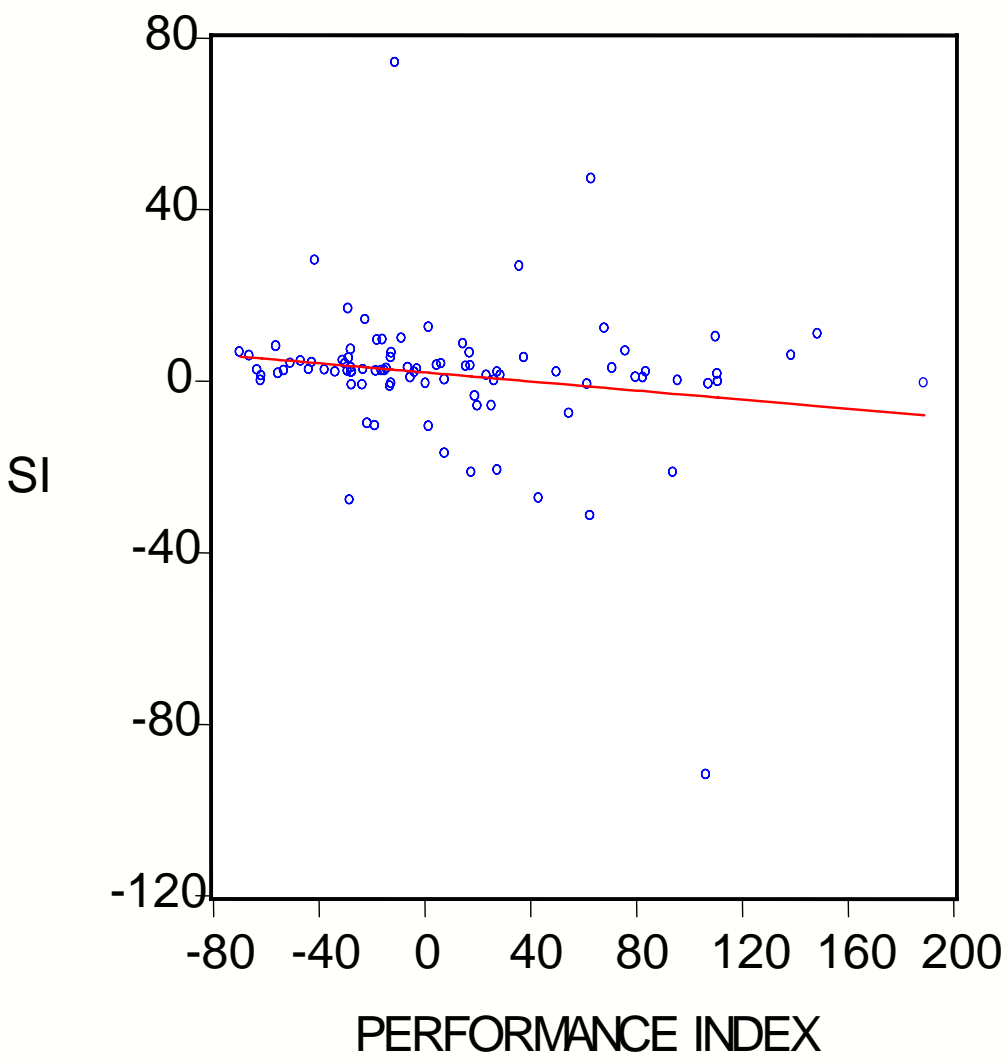


latter include the average and standard deviation (over the past 20 years) of yearly inflation, the standard deviation of output growth, and the standard deviation of M2 over GDP (all variables are detrended). Better performing central banks would be expected to obtain lower and less volatile inflation, less output volatility, and better financial stability (i.e., a more steady M2 over GDP).

The results, which appear in Table 13, fail to identify a clear link between central banks' operating expenditures and macro-financial outcomes. Higher expenditures appear to be associated with lower inflation volatility and financial volatility, but higher inflation. Significance levels are low in all cases.

Table 13. Expenditures Performance Index

\begin{tabular}{lrcrc}
\hline \multicolumn{1}{c}{ Variable } & Coefficient & Std. Error & t-Statistic & Prob. \\
\hline & & & & \\
LOG(Inflation) & 0.41 & 0.24 & $1.71^{*}$ & 0.0941 \\
LOG(GDP Volatility) & 0.13 & 0.41 & 0.32 & 0.7482 \\
LOG(Inflation Volatility) & -0.25 & 0.21 & -1.21 & 0.2332 \\
LOG(M2/GDP Volatility) & -0.11 & 0.07 & -1.62 & 0.1127 \\
C & 2.76 & 0.56 & 4.93 & 0.0000 \\
& & & & \\
R-squared & 0.127798 & Mean dependent var & & 3.456954 \\
Adjusted R-squared & 0.040578 & S.D. dependent var & 1.292247 \\
S.E. of regression & 1.265758 & Akaike info criterion & 3.413658 \\
Sum squared resid & 64.08570 & Schwarz criterion & 3.614398 \\
Log likelihood & -71.80730 & F-statistic & & 1.465231 \\
Durbin-Watson stat & 2.157605 & Prob(F-statistic) & 0.230834 \\
\hline
\end{tabular}

\section{Conclusions}

The above results, on the whole, suggest that independence and governance are both major issues for many central banks. Faced with generally soft budget constraints, resulting from large and expandable seigniorage revenues, many central banks still seem to be used by governments as residual sources of cheap finance. Notwithstanding efforts to limit new explicit financing to governments, many central banks appear to remain burdened with large nonperforming assets and compulsory transfers that limit their capital accumulation capacity. Remarkably, however, these central banks are also generally the ones that overspend more in terms of their own operating expenses. This suggests that lack of independence and lack of governance tend to go together. 
A number of preliminary policy implications may be inferred from these results.

- $\quad$ This study does not undermine the need for central bank independence. Instead, the fact that the central banks with more governance problems also seem to be the least independent strengthens the case for independence. Inversely, the fact that more independent central banks seem to have better governance should allay concerns that giving central banks more independence will lead to a free-for-all increase in central banks' expenditures. Indeed, allowing central banks to freely manage their budget and set their wage scale is particularly essential at a time when many of them need to evolve toward a "modern" concept of central banking, with few, but highly skilled, staff.

- $\quad$ Potential governance concerns do not seem to be limited to central banks with weak financial conditions, however. The fact that central banks' operating expenses (unlike dividend transfers) are strongly related to their profitability and vary widely across central banks operating under similar environments suggests that many central banks do not feel compelled to "squeeze out every penny" in favor of their shareholder. This being said, it is also remarkable that central banks' operating expenses are more closely linked to demand factors than supply factors. By itself, this supports a more benign interpretation of central bank behavior, based on a limited perspective of public welfare, rather than outright lack of governance. Many central banks try to fulfill their stability mandate the best they can, without questioning whether the marginal dollar used in such quest would be better used elsewhere in the public sector.

- Independence goes together with accountability, however. An essential prerequisite for accountability is transparency. As already noted, for many of those central banks that do publish their financial accounts, there is much room for improvement in making them more easily accessible and understandable. In particular, income statements need to clearly distinguish between transitory and permanent (structural) components. For those central banks that do not yet make their income statement public, it is, of course, high time to do so.

- $\quad$ One of the main merits of transparency is to allow for systematic peer comparisons. By facilitating studies such as this one, transparency provides the necessary benchmarking for central banks to have a clearer idea of where they stand and take appropriate action.

- $\quad$ The need for periodic reviews of central bank expenditures by governments (including as regards the cost of reserve accumulation) might be a healthy practice to ensure that criteria for comparing the provision of public goods are sufficiently uniform across the public sector. As discussed in Ize (2005), central bank recapitalizations may provide good opportunities for such broad policy debates. Arrangements such as the one introduced recently in New Zealand (whereby seigniorage income on currency belongs to the State, but a share of it, negotiated with 
the treasury every five years, is retained by the central bank for its own funding) is an interesting example of more systematic stock-taking opportunities that other central banks may wish to follow.

- $\quad$ Finally, central banks need to further their efforts toward ensuring that the services they provide are adequately priced and are paid by the users. Indeed the fact that carrying international reserves in the balance sheet is costly for many central banks provides, at least in principle, some justification for not paying the full market interest rate (i.e., not paying the risk premium) on their deposits. In this context, submitting banks to unremunerated reserve requirements, or some other fee-based mechanism whereby banks pay (and hence internalize) liquidity costs, may be justified. The difficult issue remains, however, as to what constitutes a proper level of service provided, i.e., a proper level of international reserves.

The conclusions above are subject to important caveats, however, that reflect the limitations of this study. In particular, the facts that the study rests on data from a single year and its conclusions are purely based on cross-sectional evidence raise issues of causality and hinder the distinction between stable patterns and merely circumstantial occurrences. This problem is amplified by the fact that some of the conclusions in this paper are based on simple averages. While the aggregate sample was divided into two more homogeneous subsamples and care was taken to eliminate clear outliers, the large standard deviations of many variables across the two subsamples indicate that considerable heterogeneity remains. Thus, the risk remains that some of the results may be dominated by large deviations in a few of the countries in the sample. Overcoming these problems and identifying proper dynamics and causality patterns would require a panel analysis over a sufficiently long period of time (and, therefore, a much larger investment in the preparation of the data).

In addition, assessing central bank output is inherently difficult, given the lack of counterfactual evidence on what economic performance would look like in the absence of a central bank. This problem is amplified here by the fact that this study does not make any specific inferences on central bank efficiency in the traditional sense; that is, how much output is obtained for a given input. It does not measure the quality or the quantity of central bank services (this would require having a well-defined output variable and breaking down operating expenditures into a price component-linked to staff salaries_-and a volume component-linked to employment and staff education). The performance index in this paper should thus be interpreted with caution. Clearly, more analysis is needed to firm up the main conclusions of the paper. 


\section{SAMPLE COUNTRIES}

Information on income statements for 2003 (the base year for this study) were drawn from central banks' web sites. Balance sheet information for 2002 and 2003 and all macroeconomic indicators were drawn from IFS. Other items net were consolidated with capital. From the full universe of (184) IMF member countries, a first selection had to be made to exclude those countries whose income accounts were not published, or were published in a non-easilyaccessible language. This reduced the sample to 101 countries (Table 14). The sample was reduced further for the seigniorage study, to 87 countries, after eliminating those countries that (i) did not have sufficiently detailed income statements (allowing in particular to identify net interest margins); (ii) for which no interest rate data could be obtained; or (iii) for which the flows derived from the beginning-of-period and end-of-period balance sheet information did not seem to be easily reconcilable with the income statement.

Table 14. Sample Countries

\begin{tabular}{|c|c|c|c|}
\hline Argentina & Denmark & Kuwait & Qatar* \\
\hline Armenia & El Salvador & Kyrgyz Republic & Romania \\
\hline Australia & Estonia & Latvia & Russia \\
\hline Austria & Fiji & Lebanon & Saudi Arabia* \\
\hline Azerbaijan & Finland & Lesotho* & Serbia* \\
\hline Bahamas & France & Lithuania & Sierra Leone \\
\hline Bahrain & Georgia & Luxembourg & Singapore \\
\hline Bangladesh & Germany & Macedonia & Slovakia \\
\hline Barbados & Greece & Madagascar & Slovenia \\
\hline Belarus & Guatemala & Malta* & South Africa \\
\hline Belgium & Haiti & Mauritius & Spain \\
\hline Belize & Honduras & Moldova & Sweden \\
\hline Bermuda & Hungary & Mongolia & Switzerland \\
\hline Bolivia & Iceland & Mozambique & Tanzania \\
\hline Bosnia & India & Namibia* & Thailand \\
\hline Botswana* & Indonesia & Netherlands & Tunisia \\
\hline Brazil & Iran* & New Zealand & Turkey \\
\hline Bulgaria & Ireland & Nicaragua & UAE* \\
\hline Canada & Israel & Nigeria & United Kingdom \\
\hline Cayman Isl.* & Italy & Norway & Ukraine \\
\hline Chile & Jamaica & Oman & Uruguay \\
\hline Colombia & Japan & Pakistan & United States \\
\hline Costa Rica & Jordan & Paraguay & \\
\hline Croatia & Kazakhstan & Peru & \\
\hline Cyprus & Kenya & Poland & \\
\hline Czech Republic & Korea & Portugal & \\
\hline
\end{tabular}

*/ Countries excluded from the seigniorage study. 


\title{
NotATION
}

\author{
O: $\quad$ Operating expenditures \\ Z: $\quad$ Net exceptional expenditures \\ T: $\quad$ Transfers to government \\ SI: $\quad$ Structural income \\ XF: $\quad$ Net claims on foreigners \\ XG: Net claims on government \\ XB: Net claims on banks (and on the private sector) \\ C: $\quad$ Currency \\ K: Capital \\ B: Net interest paying liabilities \\ D: Net non-interest earning assets \\ $\Phi: \quad$ Nominal risk premium \\ $\mathrm{R}$ : Domestic interest rate \\ $\mathrm{R}^{*}$ : $\quad$ Foreign interest rate \\ $\pi$ : Domestic inflation rate \\ $\pi *$ : Foreign inflation rate
}




\section{Valuation Adjustments}

Consider the general balance sheet form:

$$
K_{t}=E_{t} X_{t}^{*}+X_{t}
$$

where $X_{t}^{*}$ and $X_{t}$ stand for net foreign-currency-denominated assets and net local-currencydenominated assets at time $t$ respectively; $K_{t}$ is the central bank's capital; and $E_{t}$, the exchange rate. Assuming that valuation adjustments are applied to beginning-of-period stocks, profits can be expressed from the income statement as

$$
\Delta K_{t}=\left(R_{t}^{*}+\frac{E_{t}-E_{t-1}}{E_{t-1}}\right) E_{t-1} X_{t-1}^{*}+\left(r_{t}+\frac{P_{t}-P_{t-1}}{P_{t-1}}\right) X_{t-1},
$$

where $R_{t}{ }^{*}$ and $r_{t}$ are the nominal foreign interest rate and the real domestic interest rate, respectively, and $P_{t}$ is the domestic price level. But, taking the first differences of (A1) leads to:

$$
\Delta K_{t}=\left(E_{t} X_{t}^{*}-E_{t-1} X_{t-1}^{*}\right)+\left(X_{t}-X_{t-1}\right)
$$

which can also be decomposed into price and volume effects as

$$
\Delta K_{t}=E_{t}\left(X_{t}^{*}-X_{t-1}^{*}\right)+\frac{E_{t}-E_{t-1}}{E_{t-1}} E_{t-1} X_{t-1}^{*}+P_{t}\left(\frac{X_{t}}{P_{t}}-\frac{X_{t-1}}{P_{t-1}}\right)+\frac{P_{t}-P_{t-1}}{P_{t-1}} X_{t-1}
$$

Comparing equations (A2) and (A4), it can immediately be seen that the valuation adjustments are the same, making the income and balance sheet statements, expressed in real terms, fully consistent.

A similar decomposition can be carried out for the income statement, based on end-of-period stocks:

$$
\Delta K_{t}=\left(R_{t}^{*}+\frac{E_{t}-E_{t-1}}{E_{t}}\right) E_{t} X_{t}^{*}+\left(r_{t}+\frac{P_{t}-P_{t-1}}{P_{t}}\right) X_{t}
$$

And the first differences of equation (A1) can also be decomposed as

$$
\Delta K_{t}=E_{t-1}\left(X_{t}^{*}-X_{t-1}^{*}\right)+\frac{E_{t}-E_{t-1}}{E_{t}} E_{t} X_{t}^{*}+\left(\frac{P_{t-1}}{P_{t}} X_{t}-X_{t-1}\right)+\frac{P_{t}-P_{t-1}}{P_{t}} X_{t} .
$$

It can again be checked that (A5) and (A6) are mutually consistent. 


\section{REFERENCES}

Davidson, R., and J. MacKinnon, 1981, Several Tests for Model Specification in the Presence of Alternative Hypotheses, Econometrica, Vol. 49, No. 3, pp. 781-93.

Eichengreen, B. and D. J. Mathieson, 2000, “The Currency Composition of Foreign Exchange Reserves: Retrospect and Prospect,” IMF Working Paper 00/131 (Washington: International Monetary Fund)

Fry, M., C. Goodhart, and A. Almeida, 1996, Central Banking in Developing Countries (New York: Routledge).

Kaufmann, D., A. Kraay, and M. Mastruzzi, 2003, “Governance Matters III: Governance Indicators for 1996-2002,” World Bank Policy Research Department Working Paper.

Ize, A., 2005, “Capitalizing Central Banks: A Net Worth Approach,” Staff Papers, International Monetary Fund, Vol. 52, No. 2, pp. 289-310.

McKinley, V. and K. Banaian, 2005, Central Bank Operational Efficiency: Meaning and Measurement,” in Central Bank Modernization, ed. by Peter Nicholl and Neil Counts, (London: Central Banking Publications).

Stella, P., 1997, “Do Central Banks Need Capital?” IMF Working Paper 97/83 (Washington: International Monetary Fund). , 2005, “Central Bank Financial Strength, Transparency, and Policy Credibility,” Staff Papers, International Monetary Fund, Vol. 52, No. 2, pp. 335-65. 